\title{
QUEEN'S
UNIVERSITY
BELFAST
}

\section{Surface plasmon resonance biosensor for the determination of 3- methyl-quinoxaline-2-carboxylic acid, the marker residue of olaquindox, in swine tissues}

Peng, D., Kavanagh, O., Gao, H., Zhang, X., Deng, S., Chen, D., Liu, Z., Xie, C., Yuan, Z., \& Situ, C. (2019). Surface plasmon resonance biosensor for the determination of 3-methyl-quinoxaline-2-carboxylic acid, the marker residue of olaquindox, in swine tissues. Food Chemistry. https://doi.org/10.1016/j.foodchem.2019.04.022

Published in:

Food Chemistry

Document Version:

Peer reviewed version

Queen's University Belfast - Research Portal:

Link to publication record in Queen's University Belfast Research Portal

Publisher rights

(c) 2019 Elsevier Ltd.

This manuscript version is made available under the CC-BY-NC-ND 4.0 license http://creativecommons.org/licenses/by-nc-nd/4.0/,which permits distribution and reproduction for non-commercial purposes, provided the author and source are cited

\section{General rights}

Copyright for the publications made accessible via the Queen's University Belfast Research Portal is retained by the author(s) and / or other copyright owners and it is a condition of accessing these publications that users recognise and abide by the legal requirements associated with these rights.

Take down policy

The Research Portal is Queen's institutional repository that provides access to Queen's research output. Every effort has been made to ensure that content in the Research Portal does not infringe any person's rights, or applicable UK laws. If you discover content in the Research Portal that you believe breaches copyright or violates any law, please contact openaccess@qub.ac.uk. 


\section{Accepted Manuscript}

Surface plasmon resonance biosensor for the determination of 3-methyl-quinoxaline-2-carboxylic acid, the marker residue of olaquindox, in swine tissues

Dapeng Peng, Owen Kavanagh, Haijiao Gao, Xiya Zhang, Sijun Deng, Dongmei Chen, Zhenli Liu, Changqing Xie, Chen Situ, Zonghui Yuan

PII: $\quad$ S0308-8146(19)30671-5

DOI: $\quad$ https://doi.org/10.1016/j.foodchem.2019.04.022

Reference: $\quad$ FOCH 24623

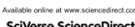

To appear in: $\quad$ Food Chemistry

Received Date: $\quad 5$ November 2018

Revised Date: $\quad 5$ April 2019

Accepted Date: $\quad 5$ April 2019

Please cite this article as: Peng, D., Kavanagh, O., Gao, H., Zhang, X., Deng, S., Chen, D., Liu, Z., Xie, C., Situ, C., Yuan, Z., Surface plasmon resonance biosensor for the determination of 3-methyl-quinoxaline-2-carboxylic acid, the marker residue of olaquindox, in swine tissues, Food Chemistry (2019), doi: https://doi.org/10.1016/ j.foodchem.2019.04.022

This is a PDF file of an unedited manuscript that has been accepted for publication. As a service to our customers we are providing this early version of the manuscript. The manuscript will undergo copyediting, typesetting, and review of the resulting proof before it is published in its final form. Please note that during the production process errors may be discovered which could affect the content, and all legal disclaimers that apply to the journal pertain. 


\section{Surface plasmon resonance biosensor for the determination of}

\section{3-methyl-quinoxaline-2-carboxylic acid, the marker residue of olaquindox,} in swine tissues

Dapeng Peng ${ }^{1}$, Owen Kavanagh ${ }^{3}$, Haijiao Gao ${ }^{1}$, Xiya Zhang ${ }^{1}$, Sijun Deng ${ }^{2}$, Dongmei Chen ${ }^{1}$, Zhenli Liu ${ }^{1}$, Changqing Xie ${ }^{1}$, Chen Situ $^{2 *}$, Zonghui Yuan ${ }^{1 *}$

${ }^{1}$ National Reference Laboratory of Veterinary Drug Residues (HZAU) and MOA Key Laboratory for the Detection of Veterinary Drug Residues in Foods Huazhong Agricultural University, Wuhan, Hubei 430070, China

${ }^{2}$ The Institute for Global Food Security, School of Biological Sciences, Queen's University Belfast, BT9 5AG, Northern Ireland, United Kingdom

${ }^{3}$ School of Health Sciences, Lord Mayor's Walk, York, Y031 7EX, UK.

${ }^{*}$ Corresponding author: Tel.: +86 278728 7186; fax: +86 278767 2232. E-mail address: c.situ @ qub.ac.uk (C. Situ), yuan5802@mail.hzau.edu.cn. (Z. Yuan) 


\section{Abstract}

2 To monitor the illegal use of olaquindox in animals, a monoclonal antibody-based surface 3 plasmon resonance (SPR) biosensor method has been developed to detect 4 3-methyl-quinoxaline-2-carboxylic acid, the marker residues of olaquindox, in swine tissues.

5 The limit of detection was $1.4 \mu \mathrm{g} \mathrm{kg}^{-1}$ in swine muscle and $2.7 \mu \mathrm{g} \mathrm{kg}^{-1}$ in swine liver, which

6 are lower than the EU recommended concentration $\left(10 \mu \mathrm{g} \mathrm{kg}^{-1}\right)$. The recoveries were from

$782 \%$ to $104.6 \%$, with coefficients of variation of less than $12.2 \%$. Good correlations between

8 SPR and HPLC results $(r=0.9806$, muscle; $r=0.9698$, liver $)$ and between SPR and ic-ELISA

9 results $(\mathrm{r}=0.9918$, muscle; $\mathrm{r}=0.9873$, liver $)$ were observed in the affected tissues, which

10 demonstrated the reliability of the SPR method. This method would be a rapid and reliable

11 tool for the screening of the residues of olaquindox in the edible tissues of animals.

13 Keywords: surface plasmon resonance biosensor; 3-methyl-quinoxaline-2-carboxylic acid;

14 olaquindox; residues; swine tissues 


\section{Introduction}

Olaquindox (OLA, Figure 1), an antibacterial growth-promoting agent in quinoxalines, was widely used in swine for the control of swine dysentery and/or bacterial enteritis in young swine, to improve feed efficiency and increase the rate of weight gain (FAO/WHO, 1990). It was also widely used in poultry and aquatic animals illegally around the world for decades (Carta, Corona, \& Loriga. 2005). However, OLA was a mutagen and suspected carcinogen with photosensitive toxicity (Eberlein, Bergner, \& Przybilla, 1992; Emmert, Schauder, Palm, Hallier, \& Emmert, 2007; FAO/WHO, 1990), renal toxicity (FAO/WHO, 1990), genotoxicity (Chen et al., 2009; FAO/WHO, 1990; Ihsan et al., 2013; Liu et al., 2016; Yang et al., 2015; Zou et al., 2009), cytotoxicity (Huang et al., 2010; Li et al., 2016; Zou et al., 2011). Therefore, the use of OLA in food-producing animals had been banned in some countries and regions (Commission Regulation (EC) No 2788/98, 1998; FAO/WHO, 1995). In China, OLA has been approved as a feed additive for piglets weighing less than $35 \mathrm{~kg}$ with a withdrawal period of 35 days (Announcement No. 168, 2001). Recently, The Ministry of Agriculture (MOA) of China stipulated that OLA will be withdrawn from market before 2020 (Announcement No. 2638, 2018).

Although regulations exist, non-compliance remains a serious issue due to the economic benefits of OLA in food animals and the broad availability of commercial OLA worldwide. Therefore, the development of a rapid and reliable detection method for screening the residues of OLA in edible tissues of food animals is necessary. Traditionally, the use of such compounds should be controlled by the analysis of their respective metabolites in the target tissues. However, because of the lack of sufficient data on metabolism and residue depletion, the acceptable daily intake of OLA has not been recommended, the marker residue (MR) of OLA was not defined, and the maximum residue limits (MRLs) of OLA were not established (FAO/WHO, 1990). Therefore, the safety of edible tissues in the animals administered with 
OLA could not be guaranteed.

In 1995, 3-methylquinoxaline-2-carboxylic acid (MQCA) was tentatively recommended as the MR of OLA by FAO/WHO (1995) for the control of OLA residues in the edible tissues of animals treated with OLA. In 2007, European Reference Laboratory proposed for MQCA in meat a recommended concentration (RC) of $10 \mu \mathrm{g} \mathrm{kg}^{-1}$ for analytical method (CRL Guidance Paper, 2007). In China, the MRLs of MQCA, which is in keeping with the report of JECFA, is set at $50 \mu \mathrm{g} \mathrm{kg}^{-1}$ in swine liver and $4 \mu \mathrm{g} \mathrm{kg}^{-1}$ in swine muscle (Announcement No. 235, 2002; FAO/WHO, 1995).

During the past decades, several physicochemical methods, including high performance liquid chromatography (HPLC) ( Wu et al., 2007; Zhang, Zheng, Zhang, Chen, \& Mei, 2011) and liquid chromatography tandem mass spectrometry (LC-MS/MS) (Boison, Lee, \& Gedir, 2009; Hutchinson, Young, \& Kennedy, 2005; Merou, Kaklamanos, \& Theodoridis, 2012), have been developed for olaquindox and its marker residue MQCA. However, due to the high cost and the need for skilled scientists, these physicochemical methods are more suitable for confirmatory analysis than screening methods. As an alternative, an antibody-based rapid and sensitive indirect competitive enzyme-linked immunosorbent assay screening method (ic-ELISA) for detecting MQCA residues had also been published (Cheng et al., 2013; Jiang, Beier, Wang, Wu, \& Shen, 2013; Yue et al., 2009; Zhang et al., 2015). Although these methods are available, they are acknowledged to be tedious with time-consuming steps such as washing, separation of bound and free antigen, and a lengthy incubation time.

The emergence of biosensor-based immunological assays, such as the optical based surface plasmon resonance (SPR) detection which is a label-free technique for the sensitive real-time monitoring of molecular interactions, in the field of food safety testing offers prominent advantages such as high sensitivity, low limit of detection, specificity and robustness (Campbell et al., 2009). In the past few years, the SPR method has been used 
successfully in the field of food safety detection (Caldow et al., 2005; Devlin et al., 2014; Hirakawa et al., 2018; Olaru, Bala, Jaffrezic-Renault, \& Aboul-Enein, 2015; Pan, Li, Wang, Sheng, \& Wang, 2017; Yuan, Deng, Lauren, Aguilar, \& Wu, 2009). Nevertheless, to our best knowledge, no SPR biosensor method has been developed for detection of MQCA residues.

Therefore, the aim of the present study was to develop and validate an SPR biosensor method for the analysis of MQCA residues in edible animal tissue samples without the necessity of a complicated sample preparation procedure.

\section{Materials and Methods}

\subsection{Chemicals and reagents}

Ovalbumin (OVA), dicyclohexylcarbodiimide (DCC), N-hydroxysuccinimide (NHS), N-ethyl-N'-(3-dimethylaminopropyl) carbodiimide hydrochloride (EDC), and ethanolamine hydrochloride (1 M, pH 8.5) were purchased from Sigma-Aldrich (St. Louis, MO, USA). A carboxymethylated dextran CM5 chip was purchased from Biacore AB (Uppsala, Sweden). HBS-EP buffer (0.01 M HEPES, 0.15 M NaCl, 3 mM EDTA and 0.005\% Surfactant P20, pH 7.4) were also purchased from Biacore AB (Uppsala, Sweden). Purified and deionized water was obtained from Millipore reverse osmosis and milli-Q polishing systems. The primary stock solution at $1 \mathrm{mg} \mathrm{mL}^{-1}$ was prepared by dissolving the compound in the purified and deionized water (milli-Q). Serial dilutions were prepared by diluting the primary stock solution in HBS-EP buffer. All other chemicals were also purchased from Sigma-Aldrich (St. Louis, MO, USA) and were of analytical grade.

The standard analytes MQCA, NH2MQCA, and NH2MQCA-OVA (shown in Figure 1) and the anti-MQCA monoclonal antibody 5B10 (mAb 5B10, $\left.1 \mathrm{mg} \mathrm{mL}^{-1}\right)$ were supplied by the Institute of Veterinary Pharmaceuticals, Huazhong Agricultural University (Wuhan, China), in which their structures and/or their characteristics had been guaranteed (Zhang et al., 2015). Briefly, the standard analyte MQCA was purchased from the Institute of Veterinary Drug 
Control (Beijing, China). The hapten NH2MQCA was identified by nuclear magnetic resonance (NMR, Bruker-400 spectrometers, Bruker BioSpin, Switzerland) and ion trap and time-of-flight mass spectrometers coupled with a HPLC system (LC/MS-ITTOF, Shimadzu, Kyoto, Japan), respectively. MS m/z calculated for $\mathrm{C}_{10} \mathrm{H}_{9} \mathrm{~N}_{3} \mathrm{O}_{2}[\mathrm{M}+\mathrm{H}]^{+}$204.0768, found 204.0763. $\mathrm{H}^{1}$ NMR (DMSO-d6) $\delta_{\mathrm{H}}: 2.73\left(\mathrm{~s}, 3 \mathrm{H}, \mathrm{C} 3-\mathrm{CH}_{3}\right), 6.84,7.23,7.39$ (each $\left.1 \mathrm{H}, \mathrm{Ar}-\mathrm{H}\right)$, 4.60 (br, $2 \mathrm{H},-\mathrm{NH}_{2}$ ), 12.0 13.0 (br, $\left.1 \mathrm{H},-\mathrm{COOH}\right)$. The synthesized coating conjugate NH2MQCA-OVA was characterized by 8453 UV-Visible spectrophotometer (Aglient 8453, USA), which the estimated incorporation rates of conjugates is 9.7. The obtained specific mAb 5B10 that has isotype IgG1 showed an $\mathrm{IC}_{50}$ value of $17.7 \mu \mathrm{gL}^{-1}$ for MQCA and did not exhibit measurable cross-reactivity $(\mathrm{CR})$ with other quinoxalines and their analogues $(\mathrm{CR}<$ $0.1 \%$ ) such as OLA, quinocetone, mequindox, cyadox, carbadox, quinoxaline-2-carboxylic acid, desoxymequindox, desoxyquinocetone, and desoxyolaquindox (Zhang et al., 2015).

\subsection{Immobilization of ligand on CM5 chip}

As shown in Figure 1, the NH2MQCA contains a standard amino group. Therefore, it is immobilized covalently on a CM5 chip by an amine coupling procedure in two steps according to Campbell's procedure (Campbell et al., 2009) with modification. Briefly, the chip was allowed to equilibrate to room temperature, and a continuous flow of HBS-EP buffer passing over the sensor surface at a flow rate of $5 \mu \mathrm{L} \min ^{-1}$ was maintained. OVA, as a ligand, was first immobilized on the CM5 chip surface. In this procedure, the carboxyl groups on the CM5 chip surface were activated by $50 \mu \mathrm{L}$ of a $1: 1 \quad(\mathrm{v} / \mathrm{v})$ mixture of $0.4 \mathrm{M}$ 1-ethyl-3-(3-dimethylaminopropyl) carbodiimide hydrochloride $\quad$ (EDC) and $0.1 \quad \mathrm{M}$ N-hydroxysuccinimide (NHS) at a flow rate of $7 \mu \mathrm{L} \mathrm{min}^{-1}$ for $7 \mathrm{~min}$. OVA $\left(10 \mathrm{mg} \mathrm{ml}^{-1}, \mathrm{pH}\right.$ 4.0, $10 \mathrm{mM}$ sodium acetate (NaAc) buffer) was run onto the activated chip at a flow rate of 6 $\mu \mathrm{L} \min ^{-1}$ for $15 \mathrm{~min}$, with OVA immobilized on the CM5 chip. The remaining un-reacted groups on the sensor surface were deactivated by the injection of ethanolamine- $\mathrm{HCl}(1 \mathrm{M}, \mathrm{pH}$ 
1158.5 ) at a flow rate of $5 \mu \mathrm{L} \mathrm{min}{ }^{-1}$ for $7 \mathrm{~min}$. After the surface was washed with $10 \mathrm{mM}$ sodium

116 hydroxide $(\mathrm{NaOH})$ at a flow rate of $20 \mu \mathrm{L} \mathrm{min}^{-1}$ for 1 min (this step was repeated 3 times), 10

$117 \mathrm{mM}$ glycine- $\mathrm{HCl}(\mathrm{pH} 3.0)$ was used to regenerate the chip at a rate of $20 \mu \mathrm{L} \mathrm{min}{ }^{-1}$ for $1 \mathrm{~min}$.

118 Second, the same procedure was used to immobilize the ligand NH2MQCA $\left(200 \mu \mathrm{g} \mathrm{mL}^{-1}\right)$ on

119 the surface of the chip and/or on the carrier protein OVA that had been immobilized on the

120 surface of the chip. Finally, the chip surface was washed with deionized water, then dried

121 under a stream of nitrogen gas, and stored in a desiccated container $\left(4^{\circ} \mathrm{C}\right)$

2.3 Optimization of the SPR-biosensor analytical conditions

The optical surface plasmon resonance (SPR) biosensor used was a Biacore 3000 (GE

Healthcare, Sweden) with Biacore ${ }^{\circledR}$ Q control software version 3.0.1, which was used for the

sensorgram and data analysis. Because the BIACORE Q Control Software offered a suitable

means of developing and running projects automatically under controlled conditions, only

limited parameters were necessary for the investigation of the development of the Biacore

3000 biosensor assay, including binder dilution, ratio of binder to standard, injection volume,

contact time, and the regeneration solution. In this project, studies were conducted at $25{ }^{\circ} \mathrm{C}$.

Briefly, mAb 5B10 $\left(1 \mathrm{mg} \mathrm{mL}^{-1}\right)$ was diluted in HBS-EP buffer $(1: 100,1: 200,1: 500,1: 800$,

1:1000) and was tested to determine the optimal concentration of antibody dilution for the inhibition assay in the biosensor (200-300 resonance units (RU)). To test the optimal ratio of binder to standard, injection volume, and contact time, the standard solution was transferred into the wells of a U-bottomed microtitre plate (Greiner Bio One, Gloucestershire, UK) and mixed with antibody solution in different ratios $(3: 1,2: 1,1: 1,1: 2,1: 3$, v/v) by the autosampler via the control software. Then, the mixtures were injected over the sensor chip surface at different flow rates $\left(15,20,25 \mu \mathrm{L} \mathrm{min}{ }^{-1}\right)$ for different times $(150 \mathrm{~s}, 240 \mathrm{~s}$, and 300 s). In addition, chip surface regeneration was performed to reuse the sensor chip. 
140 the surface but leaves the ligand attached to the chip surface so another sample can be analysed. To test for the optimal regeneration solution, different concentrations of $\mathrm{NaOH}$ solution (5 mM, $10 \mathrm{mM}, 20 \mathrm{mM})$ and glycine- $\mathrm{HCl}(\mathrm{pH} 3.0)$ solution $(5 \mathrm{mM}, 10 \mathrm{mM}, 20 \mathrm{mM})$ were used.

\subsection{Preparation of standards for SPR analysis}

To compare the calibration curves prepared from extracts of the different tissue matrices following extraction with the extracts prepared in HBS-EP buffer, three standard curves were prepared. The standard dose response curve was obtained according to the RU values and concentrations of standards. The standard curves were fitted using the following equation: $\mathrm{y}=(\mathrm{A}-\mathrm{D}) /\left[1+(\mathrm{x} / \mathrm{C})^{\wedge} \mathrm{B}\right]+\mathrm{D}$. where $\mathrm{A}$ and $\mathrm{D}$ are the responses at high and low asymptotes of the curve, respectively, $\mathrm{C}$ is the concentration of the targets resulting in $50 \%$ inhibition, $\mathrm{B}$ is the slope at the inflection point of the sigmoid, and $\mathrm{X}$ is the calibration concentration.

For standard curve A, a calibration curve consisting of five concentrations was constructed by diluting the MQCA stock standard $\left(1000 \mu \mathrm{gL}^{-1}\right)$ in HBS-EP buffer, ranging from 0 to $100 \mathrm{ng} \mathrm{mL}^{-1}\left(0,6.25,12.5,25,50,100 \mathrm{ng} \mathrm{mL}^{-1}\right)$.

To prepare standard curve B, known negative tissue was extracted as described for sample preparation, and aliquots $(1 \mathrm{~mL})$ were spiked with MQCA stock standard $(1000 \mu \mathrm{g}$ $\left.\mathrm{mL}^{-1}\right)$ to provide 5 calibration standards $\left(0,6.25,12.5,25,50,100 \mathrm{ng} \mathrm{mL}^{-1}\right)$ for the calibration curve.

To prepare standard curve $\mathrm{C}$, known negative tissue was spiked with known amounts of MQCA at $0 \mu \mathrm{g} \mathrm{kg}^{-1}, 6.25 \mu \mathrm{g} \mathrm{kg}^{-1}, 12.5 \mu \mathrm{g} \mathrm{kg}^{-1}, 25 \mu \mathrm{g} \mathrm{kg}^{-1}, 50 \mu \mathrm{g} \mathrm{kg}^{-1}$, and $100 \mu \mathrm{g} \mathrm{kg}^{-1}$ and then extracted as described for sample preparation to obtain 5 calibration standards for the calibration curve.

2.5 Sample preparation

Samples such as swine muscle and liver were minced and homogenized. Each 
homogenized sample ( $2 \mathrm{~g})$ was weighed into a $50-\mathrm{mL}$ polypropylene centrifuge tube. Ethyl acetate $(6 \mathrm{~mL})$ and $3.0 \mathrm{~mL}$ of $1.25 \mathrm{M} \mathrm{HCl}$ were added, and the mixture was vortex-mixed for $3 \mathrm{~min}$ and then centrifuged for $5 \mathrm{~min}$ at $4000 \times \mathrm{g}$. The supernatant $(4 \mathrm{~mL})$ was transferred into another $50-\mathrm{mL}$ polypropylene centrifuge tube, $4 \mathrm{~mL}$ of saturated $\mathrm{NaCl}$ solution was added, and the solution was mixed for $1 \mathrm{~min}$. After standing for $5 \mathrm{~min}, 3 \mathrm{~mL}$ of ethyl acetate was dried using nitrogen gas at $50{ }^{\circ} \mathrm{C}$. Then, the muscle sample residue was re-dissolved with 1 $\mathrm{mL}$ of HSB-EP buffer, and the liver sample residue was re-dissolved with $3 \mathrm{~mL}$ of $\mathrm{HSB}-\mathrm{EP}$ buffer and washed with $1 \mathrm{~mL}$ of hexane. After being centrifuged for $5 \mathrm{~min}$ at $4000 \times \mathrm{g}$, the water phase was filtered with a $0.45-\mu \mathrm{m}$ filter and was then used in the SPR.

\subsection{Validation of the SPR}

Because China is the world's largest OLA consumption country, accounting for more than $80 \%$ of OLA consumption in the world, the document $\lceil 2005\rceil$ No. 17 issued by the Ministry of Agriculture veterinary bureau (2005) was therefore selected for the validation of the SPR method. According to this document, some parameters including limit of determination (LOD), accuracy and precision were determined to validate the SPR method based on the optimized standard curve and the sample preparation procedure. Briefly, 20 known negative swine muscle and liver samples, purchased from a local supermarket (Tesco, Marks \& Spencer, Sainsbury's) and previously been proven by HPLC analysis (Wu et al., 2007) to be free of OLA and its MR MQCA, were analysed by the SPR method. The determination of the LOD was based on 20 blank samples accepting no false positive rates, with an average +3 standard deviation $(\mathrm{SD})$. The accuracy and precision of the method were expressed by the recovery and coefficient of variation $(\mathrm{CV})$, respectively. The recovery (percentage) of MQCA was established using five spiked duplicate blanks at levels of $1 / 2 \mathrm{MRL}$ (2 $\mu \mathrm{g} \mathrm{kg}^{-1}$ in muscle and $25 \mu \mathrm{g} \mathrm{kg}^{-1}$ in liver), MRL (4 $\mu \mathrm{g} \mathrm{kg}^{-1}$ in muscle and $50 \mu \mathrm{g} \mathrm{kg}^{-1}$ in liver) and 2MRL ( $8 \mu \mathrm{g} \mathrm{kg}^{-1}$ in muscle and $100 \mu \mathrm{g} \mathrm{kg}{ }^{-1}$ in liver) obtained from three different 
analyses and was calculated using the following equation: (concentration measured/concentration spiked) $\times 100$. CVs were determined by analysing samples spiked with MQCA at the same levels of above from five different analyses. Each concentration level was tested three times in a time span of 2 months.

\subsection{Comparison of the SPR biosensor with ic-ELISA and HPLC}

To test the detection capability of the developed SPR biosensor, seven pig samples were supplied by the National Reference Laboratory of Veterinary Drug Residues (Huazhong Agricultural University, HZAU) and MOA Key Laboratory for the Detection of Veterinary Drug Residues in Foods (Wuhan, China). In addition, thirty-five unknown samples, including seventeen swine muscle samples and eighteen swine liver samples that were collected from Northern Ireland by Chen in 2012 were also prepared. These samples were analysed by the current SPR biosensor, the ic-ELISA method and the HPLC analysis.

The ic-ELISA method was performed according to the publication (Zhang et al., 2015) that was developed using the same mAb 5B10. The limits of detection ranged from $1.9 \mu \mathrm{g}$ $\mathrm{kg}^{-1}$ to $4.3 \mu \mathrm{g} \mathrm{kg}^{-1}$. The recoveries ranged from $74.2 \%$ to $98.9 \%$ with a maximum of $17.3 \%$ for the CV. The HPLC analyses were performed according to the procedure of Wu et al. (2007) with modifications. Briefly, all HPLC analyses were performed using a Waters HPLC system, comprising a 2695 ternary pump and 2487 UV detection. An Eclipse XDB-C18 (250 mm, 4.6 mm I.D.) (Agilent Technology, USA) HPLC column was used for sample separation. The temperature of the HPLC column was set at $30{ }^{\circ} \mathrm{C}$. The mobile phase was acetonitrile/water containing $1 \%$ acetic acid (18:82 v/v for the plasma, muscle, liver, and fat samples; 20:80 v/v for the kidney samples). The mobile phase was pumped at a flow rate of $1.0 \mathrm{~mL} \mathrm{~min}^{-1}$. The spectra of all the samples were obtained from detection at the wavelength of $320 \mathrm{~nm}$.

\section{Results and Discussion}

\subsection{SPR analysis format design}


One of the most challenging steps for an SPR-based assay is the design of the analysis format. In this study, two formats (shown in Figure 2) were designed to perform the SPR analysis. Format A used NH2MQCA as the ligand which was immobilized on the CM5 chip surface using an amine coupling method (EDC/NHS was used to activate the carboxymethylated CM5 chip surface before the NH2MQCA was immobilized). Format B was similar to format A except in using the carrier protein OVA as a linker. For format A, obtaining an obvious change of RU value was easily accomplished. However, in some instances, the small molecular NH2MQCA directly immobilized on the CM5 chip surface was unstable, resulting in unacceptably low levels of immobilised ligand. For all these reasons, format B was selected to perform the SPR analysis.

3.2 The optimization of the SPR-biosensor analytical conditions and procedure

An antibody dilution of $1 / 500(\mathrm{v} / \mathrm{v})$ was found to give satisfactory results under the assay conditions. The samples (calibrants and spiked samples) were transferred into the wells of a U-bottomed microtitre plate and mixed with antibody solution at a ratio of $1: 1(\mathrm{v} / \mathrm{v})$ by the autosampler via the control software and injected for $240 \mathrm{~s}$ over the sensor chip surface at a rate of $20 \mu \mathrm{L} \mathrm{min}^{-1}$. The chip surface was regenerated between cycles using $10 \mathrm{mM}$ sodium hydroxide for $60 \mathrm{~s}$ at a flow rate of $20 \mu \mathrm{L} \mathrm{min}^{-1}$ and then using $10 \mathrm{mM}$ glycine- $\mathrm{HCl}$ (pH 3.0) for $60 \mathrm{~s}$ at a flow rate of $20 \mu \mathrm{L} \mathrm{min}{ }^{-1}$. The binding of the antibody to the chip surface was measured as the change in SPR signal between two reported points before (10 s) and after (20 s) each injection. A competitive immunoassay assay format (format B that was described in section 3.1) was used to detect inhibition of antibody binding to the chip surface. The SPR signal was expressed in arbitrary RUs. In this format, as the MQCA concentration increases, more anti-MQCA antibody is bound resulting in fewer antibodies binding to the ligand on the sensor surface. This inhibition of antibody binding to the ligand indicates that the RU readout is inversely related to the MQCA concentration. Standards and samples were analysed in 
duplicate.

The efficiency of immobilization was tested by assessing the $R_{\max }$ value. $R_{\max }$ provides useful information on how effective the immobilized ligand is, in contact with its binding partner. $\mathrm{R}_{\max }$ is the maximum binding capacity of the NH2MQCA (ligand) for the anti-MQCA antibody, as measured in RUs. In this study, the $\mathrm{R}_{\max }$ that was obtained was 1084.5 RUs achieved by injecting a high concentration (1/10) of anti-MQCA monoclonal antibody (5B10) over the chip surface for an extended time (15 min).

\subsection{Standard curves}

In general, matrix matched standard curves are used to reduce potential matrix effects in the analytical procedure (Diblikova, Cooper, Kennedy, \& Franek, 2005). However, the preparation of matrix-matched standards from blank samples prior to analysis might be less favourable (when multiple sample tissues are involved) for incorporation into a commercial kit. In order to adapt the test to be commercially viable, three different standard curves were compared in this study to determine if a buffer matrix would suffice. As shown in Figure 3A, the HBS-EP buffer-based standard curve (standard curve A) and the matrix-based standard curves (standard curve B and standard curve C) were obtained. Upon comparing these standard curves, good correlations between standard curve A and standard curve B (Figure 3B, $r=0.9968$ ) and between the standard curve A and standard curve $C$ (Figure 3C, $r=0.9922$ ) were observed. Therefore, standard curve A was selected for this study. Under these optimized conditions, the sensitivity $\left(\mathrm{IC}_{50}\right)$ of the SPR assay was $12.9 \mathrm{ng} \mathrm{mL}^{-1}$.

\subsection{SPR method validation and compared with ic-ELISA and HPLC analysis}

The sample preparation procedures play an important role in the development of the SPR method. In this study, ethyl acetate and $\mathrm{HCl}$ were used successfully to extract MQCA compounds from swine muscle and liver samples. Hexane was used to eliminate most of the fat during the extraction procedure. Then, $0.45-\mu \mathrm{m}$ syringe filters (Whatman, GE Healthcare 
Life Sciences) were used to remove particulate matter from the extract. This approach is consistent with the study of Zhang et al. (2015) except for the use of the filter.

As shown in Table 1, based on the results from twenty different blank samples, the LODs of the method were $1.4 \mu \mathrm{g} \mathrm{kg}^{-1}$ and $2.7 \mu \mathrm{g} \mathrm{kg}^{-1}$ in swine muscle and swine liver, respectively, which are lower than the $\mathrm{RC}\left(10 \mu \mathrm{g} \mathrm{kg}^{-1}\right)$ by EU. As described in the introduction, OLA is still used in China and the MRLs of the MR which defined as MQCA had been set at $50 \mu \mathrm{g} \mathrm{kg}^{-1}$ in swine liver and $4 \mu \mathrm{g} \mathrm{kg}^{-1}$ in swine muscle. Therefore, three concentration levels, including 1/2 MRL, MRL, and 2MRL were selected to evaluate the accuracy and precision of the SRP method in this study. As shown in Table 1, the recoveries of swine muscle and swine liver samples spiked with MQCA at the above three concentration levels were in the range of $82 \%$ to $104.6 \%$, with CVs less than $12.2 \%$. These data indicated that the SPR method fill the need for the rapid screening determination of MQCA residues in swine tissues.

As shown in Figure 4, the calculated concentrations from the standard curve with each technique (ic-ELISA, HPLC, SPR) were compared. Good correlations ( $\mathrm{r}=0.9698$, SPR and HPLC; $r=0.9873$, SPR and ic-ELISA) were observed in the swine liver tissues (Figure 4A). Similarly, good correlations $(r=0.9806$, SPR and HPLC; $r=0.9918$, SPR and ic-ELISA) were also observed in the swine muscle tissues (Figure 4B). For the thirty-eight unknown samples, no MQCA could be detected by SPR, ELISA, or HPLC analysis. These data suggested that the SPR method is reliable.

In 2015, an ic-ELISA method was developed to determine the residue of MQCA in edible animal tissues using the same mAb 5B10 (Zhang et al., 2015). Comparison between the SPR method and the ic-ELISA method was therefore reasonable. As shown in Table 2, compared with the ic-ELISA method, the SPR method is label-free, more sensitive $\left(\mathrm{IC}_{50}, 12.9\right.$ $\mathrm{ng} \mathrm{mL} \mathrm{m}^{-1}$ in SPR $<17.7 \mathrm{ng} \mathrm{mL}^{-1}$ in ic-ELISA), more precise $(\mathrm{CVs}, 12.2 \%$ in $\mathrm{SPR}<17.3 \%$ 
in ic-ELISA).

\section{Conclusions}

In this study, a mAb-based SPR method for monitoring MQCA in swine muscle and swine liver was developed with label-free, high sensitivity $\left(\mathrm{IC}_{50}, 12.9 \mathrm{ng} \mathrm{mL} \mathrm{m}^{-1}, \mathrm{LOD}, 1.4 \mu \mathrm{g}\right.$ $\mathrm{kg}^{-1}$ in swine muscle and $2.7 \mu \mathrm{g} \mathrm{kg}^{-1}$ in swine liver), good accuracy (recovery ranged from $82 \%$ to $104.6 \%)$ and precision (CVs, $12.2 \%)$. Obviously, the LODs are lower than both the EU RC $\left(10 \mu \mathrm{g} \mathrm{kg}^{-1}\right)$ and the Chinese MRL $\left(50 \mu \mathrm{g} \mathrm{kg}^{-1}\right.$ in swine liver and $4 \mu \mathrm{g} \mathrm{kg}^{-1}$ in swine muscle). The HBS-EP buffer-based standard curve make it more convenient to incorporate into the kit format that can be fully transferable to other laboratories. In summary, the SPR method for MQCA, although no longer in its infancy as a new technology, offers the ability for rapid and reliable detection of trace amounts of MQCA, the marker residues of OLA, in food of animal origin and its implementation will enable timely corrective actions to be taken to prevent unsafe food from entering into the food supply chain.

\section{organizations that can inappropriately influence our work, there is no professional or other} personal interest of any nature or kind in any product, service and/or company that could be construed as influencing the position presented in, or the review of, the manuscript entitled

"Surface plasmon resonance biosensor for the determination of 3-methyl-quinoxaline-2-carboxylic acid, the marker residue of olaquindox, in swine tissues".

\section{Acknowledgements}

The authors are grateful to the Ministry of Science and Technology of the People's 
316 Republic of China (2011DFA32140), the National Natural Science Foundation of China

317 (31772074) and the Fundamental Research Funds for the Central Universities 318 (2662017PY049, 2017BC010) for their financial support.

319 We are also grateful to Katrina Campbell, Christopher Elliott, Nitsara Karoonuthaisiri,

320 Michalina Oplatowska-Stachowiak, Kevin Cooper, and Brett Greer for their warm and sincere 321 help. 


\section{References}

Announcement No. 168. (2001). Code of practice for the use of feed Drug additives. Ministry of Agriculture of the People's Republic of China.

Announcement No. 235. (2002). Maximum residue limit of veterinary drugs in animal foods. Ministry of Agriculture of the People's Republic of China.

Announcement No. 2638. (2018). Ministry of Agriculture of the People's Republic of China.

Boison, J.O., Lee, S.C., Gedir, R.G. (2009). A determinative and confirmatory method for residues of the metabolites of carbadox and olaquindox in porcine tissues. Analytica Chimica Acta, 637, 128-134.

Caldow, M., Stead, S.L., Day, J., Sharman, M., Situ, C., Elliott, C.T. (2005). Development and validation of an optical SPR biosensor assay for tylosin residues in honey. Journal of Agricultural and Food Chemistry, 53(19), 7367-7370.

Campbell, K., Huet, A., Charlier, C., Higgins, C., Delahaut, P., Elliott, C.T. (2009). Comparison of ELISA and SPR biosensor technology for the detection of paralytic shellfish poisoning toxins. Journal of Chromatography B, 877, 4079-4089.

Carta, A., Corona, P., \& Loriga, M. (2005). Quinoxaline 1,4-dioxide: a versatile scaffold endowed with manifold activities. Current Medicinal Chemistry, 12(19), 2259-2272.

Chen, Q., Tang, S., Jin, X., Zou, J., Chen, K., Zhang, T., Xiao, X. (2009). Investigation of the genotoxicity of quinocetone, carbadox and olaquindox in vitro using Vero cells. Food and Chemical Toxicology, 47, 328-334.

Cheng, L., Shen, J., Wang, Z., Jiang, W., Zhang, S. (2013). A sensitive and specific ELISA for determining a residue marker of three quinoxaline antibiotics in swine liver. Analytical 
and Bioanalytical Chemistry, 405, 2653-2659.

Commission Regulation (EC) No 2788/98. (1998). Commission Regulation (EC) No 2788/98 of 22 December 1998 amending Council Directive 70/524/EEC concerning additives in feedingstuffs as regards the withdrawal of authorisation for certain growth promoters. Official Journal of the European Communities, L347, 31-32.

CRL Guidance Paper. (2007). CRLs view on state of the art analytical methods for national residue control plans. CRL Guidance Paper (7 December 2007), p7.

Devlin, S., Meneely, J.P., Greer, B., Campbell, K., Vasconcelos, V., Elliott, C.T. (2014). Production of a broad specificity antibody for the development and validation of an optical SPR screening method for free and intracellular microcystins and nodularin in cyanobacteria cultures. Talanta, 122, 8-15.

Diblikova, I., Cooper, K. M., Kennedy, D. G., Franek, M. (2005). Monoclonal antibody-based ELISA for the quantification of nitrofuran metabolite 3-amino-2-oxazolidinone in tissues using a simplified sample preparation. Analytica Chimica Acta. 540, 285-292

Document [2005] No.17. (2005). Reference criteria for the recording the reagent (kit) of veterinary drug residue. The Ministry of Agriculture Veterinary Bureau.

Eberlein, B., Bergner, T., Przybilla, B. (1992). Demonstration of olaquindox phototoxicity in vitro. Photodermatol Photoimmunol Photomed, 9 (2), 63-66.

Emmert, B., Schauder, S., Palm, H., Hallier, E., Emmert, S. (2007). Disabling work-related persistent photosensitivity following photoallergic contact dermatitis from chlorpromazine and olaquindox in a pig breeder. Annals of Agricultural and 
Environmental Medicine, 14 (2), 329-333.

FAO/WHO. (1990). Thirty-sixth report of the Joint FAO/WHO Expert Committee on Food Additives: Evaluation of certain veterinary drug residues in food, World Health Organ Technical Report Series, NO.799, 23-54.

FAO/WHO. (1995). Fouty-second report of the Joint FAO/WHO Expert Committee on Food Additives: Evaluation of certain veterinary drug residues in food, World Health Organ Technical Report Series, NO.851, 19-22.

Hirakawa, Y., Yamasaki, T., Harada, A., Iwasa, S., Narita, H., Miyake, S. (2018). Development of an immunosensor based on surface plasmon resonance for simultaneous residue analysis of three pesticides -boscalid, clothianidin, and nitenpyram- in vegetables. Analytical Sciences, 34(5), 533-539.

Huang. X., Zhang, H., Wang, X., Huang, L., Zhang, L., Yan, C., Liu, Y., Yuan, Z. (2010). ROS mediated cytotoxicity of porcine adrenocortical cells induced by QdNOs derivatives in vitro. Chemico-Biological Interactions, 185 (3), 227-234.

Hutchinson, M.J., Young, P.B., Kennedy, D.G. (2005). Confirmation of carbadox and olaquindox metabolites in porcine liver using liquid chromatography-electrospray, tandem mass spectrometry. Journal of Chromatography B, 816, 15-20.

Ihsan, A., Wang, X., Zhang, W., Tu, H., Wang, Y., Huang, L., Iqbal, Z., Cheng, G., Pan, Y., Liu, Z., Tan, Z., Zhang, Y., Yuan, Z. (2013). Genotoxicity of quinocetone, cyadox and olaquindox in vitro and in vivo. Food and Chemical Toxicology, 59, 207-214.

Jiang, W., Beier, R.C., Wang, Z., Wu, Y., Shen, J. (2013). Simultaneous screening analysis of 3-methyl-quinoxaline-2-carboxylic acid and quinoxaline-2-carboxylic acid residues in 
edible animal tissues by a competitive indirect immunoassay. Journal of Agricultural and Food Chemistry, 61, 10018-10025.

Li, D., Dai, C., Zhou, Y., Yang, X., Zhao, K., Xiao, X., Tang, S. (2016). Effect of GADD45a on olaquindox-induced apoptosis in human hepatoma G2 cells: Involvement of mitochondrial dysfunction. Environmental Toxicology and Pharmacology, 46, 140-146.

Liu, Q., Zhang, J., Luo, X., Ihsan, A., Liu, X., Dai, M., Cheng, G., Hao, H., Wang, X., Yuan, Z.

Olaru, A., Bala, C., Jaffrezic-Renault, N., Aboul-Enein, H.Y. (2015). Surface plasmon resonance (SPR) biosensors in pharmaceutical analysis. Critical Reviews in Analytical Chemistry, 45(2): 97-105.

Pan, M., Li, S., Wang, J., Sheng, W., Wang, S. (2017). Development and validation of a reproducible and label-free surface plasmon resonance immunosensor for enrofloxacin detection in animal-derived foods. Sensors (Basel). 17(9). pii: E1984.

Wu, Y., Yu, H., Wang, Y., Huang, L., Tao, Y., Chen, D., Peng, D., Liu, Z., Yuan, Z. (2007). Development of a high-performance liquid chromatography method for the simultaneous quantification of quinoxaline-2-carboxylic acid and methyl-3-quinoxaline-2-carboxylic acid in animal tissues. Journal of Chromatography A, 1146, 1-7. 
Yang, Y., Jiang, L., She, Y., Chen, M., Li, Q., Yang, G., Geng, C., Tang, L., Zhong, L., Jiang, L., Liu, X. (2015). Olaquindox induces DNA damage via the lysosomal and mitochondrial pathway involving ROS production and p53 activation in HEK293 cells. Environmental Toxicology and Pharmacology, 2015, 40 (3), 792-799.

Yuan, J., Deng, D., Lauren, D.R., Aguilar, M., Wu, Y. (2009). Surface plasmon resonance biosensor for the detection of ochratoxin A in cereals and beverages. Analytica Chimica Acta, 656, 63-71.

Yue, N., Ji, B., Liu, L., Tao, G., Eremin, S.A., Wu, L. (2009). Synthesis of olaquindox metabolite, methyl-3-quinoxaline-2-carboxylic acid for development of an immunoassay. Food and Agricultural Immunology, 20, 173-183.

Zhang, X., Peng, D., Pan, Y., Wang, Y., Chen, D., Zhou, Q., Liu, Z., Yuan, Z. (2015). A novel hapten and monoclonal-based enzyme-linked immunosorbent assay for 3-methyl-quinoxaline-2-carboxylic acid in edible animal tissues. Analytical Methods, 7, 6588-6594.

Zhang, X., Zheng, B., Zhang, H., Chen, X., Mei, G. (2011). Determination of marker residue of Olaquindox in fish tissue by ultra performance liquid chromatography-tandem mass spectrometry. Journal of Separation Science, 34, 469-474.

Zou, J., Chen, Q., Jin, X., Tang, S., Chen, K., Zhang, T., Xiao, X. (2011). Olaquindox induces apoptosis through the mitochondrial pathway in HepG2 cells. Toxicology, 285 (3), 104-113.

Zou, J., Chen, Q., Tang, S., Jin, X., Chen, K., Zhang, T., Xiao, X. (2009). Olaquindox-induced genotoxicity and oxidative DNA damage in human hepatoma G2 (HepG2) cells. 
434

435

436

437

438

439

440

441

442

443

444

445

\section{Figure legends}

Figure 1 The chemical structure of olaquindox and its metabolite

Figure 2 The design of the format of the SPR analysis

Figure 3 Standard curves for the quantification of MCQA. (A) three standard curves based on different matrices. - standard curve A, the HBS-EP buffer matrix; standard curve $\mathrm{B}$, the blank extract-based matrix; $\Delta$ standard curve $\mathrm{C}$, the spiked extract based matrix (B) comparison of standard curves A and $B, y=0.9296 x+12.066, r=0.9968 ;(C)$, comparison of standard curves $\mathrm{A}$ and $\mathrm{C}, \mathrm{y}=0.8979 \mathrm{x}+27.753, \mathrm{r}=0.9922$

Figure 4 Comparison with SPR, ic-ELISA and HPLC analysis in edible swine tissues.

(A) comparison with SPR, ic-ELISA and HPLC analysis in swine liver samples; (B) comparison with SPR, ic-ELISA and HPLC analysis in swine muscle samples. 
Table Titles

447

Table 1 The LOD, recoveries and coefficients of variation (CVs) of the SPR

Table 2 Comparison between the SPR method and the ic-ELISA method

449 
450

451

swine liver

2.7

Table 1 The LOD, recoveries and coefficients of variation $(\mathrm{CVs})$ of the SPR

\begin{tabular}{ccccc}
\hline tissues & $\begin{array}{c}\text { LOD } \\
\left(\mu \mathrm{g} \mathrm{kg}^{-1}\right)\end{array}$ & $\begin{array}{c}\text { spiked level } \\
\left(\mu \mathrm{g} \mathrm{kg}^{-1}\right)\end{array}$ & $\begin{array}{c}\text { mean } \\
\text { recovery }(\%)\end{array}$ & $\begin{array}{c}\mathrm{CV} \\
(\%)\end{array}$ \\
\hline swine muscle & 1.4 & 2 & $104.6 \pm 12.0$ & 11.5 \\
& & 4 & $89.9 \pm 9.8$ & 10.9 \\
swine liver & 2.7 & 25 & $82.0 \pm 6.7$ & 8.2 \\
& & 50 & $87.1 \pm 7.7$ & 8.8 \\
& & 100 & $96.1 \pm 4.2$ & 4.3 \\
\hline
\end{tabular}




\begin{tabular}{|c|c|c|}
\hline items & SPR method & ic-ELISA method ${ }^{\mathrm{a}}$ \\
\hline antibody & Monoclonal antibody 5B10 & Monoclonal antibody 5B10 \\
\hline $\mathrm{IC}_{50}\left(\mathrm{ng} \mathrm{mL}^{-1}\right)$ & 12.9 & 17.7 \\
\hline $\operatorname{LOD}\left(\mu \mathrm{g} \mathrm{kg}^{-1}\right)$ & $\begin{array}{l}1.4 \mu \mathrm{g} \mathrm{kg}^{-1} \text { in swine muscle } \\
2.7 \mu \mathrm{g} \mathrm{kg}^{-1} \text { in swine liver }\end{array}$ & $\begin{array}{l}1.9 \mu \mathrm{g} \mathrm{kg}^{-1} \text { in swine muscle } \\
4.3 \mu \mathrm{g} \mathrm{kg}^{-1} \text { in swine liver }\end{array}$ \\
\hline recovery & from $82 \%$ to $104.6 \%$ & from $74.2 \%$ to $98.9 \%$ \\
\hline $\begin{array}{l}\text { coefficient of } \\
\text { variation }\end{array}$ & $<12.2 \%$ & $<17.3 \%$ \\
\hline $\begin{array}{l}\text { the sample } \\
\text { preparation }\end{array}$ & $\begin{array}{l}\text { ethyl acetate, } \mathrm{HCl} \text {, saturated } \\
\mathrm{NaCl} \text { solution, } \mathrm{HSB}-\mathrm{EP} \text { buffer, } \\
\text { hexane, } 0.45-\mu \mathrm{m} \text { filter }\end{array}$ & $\begin{array}{l}\text { ethyl acetate, } \mathrm{HCl} \\
\text { saturation } \mathrm{NaCl} \text { solution, } \\
\text { phosphate buffer, hexane }\end{array}$ \\
\hline $\begin{array}{l}\text { detection time (does } \\
\text { not include the } \\
\text { sample preparation } \\
\text { time) }\end{array}$ & 5 min sample ${ }^{-1}$ & $\begin{array}{l}90 \text { min } \mathrm{kit}^{-1} \quad(2 \sim 3 \quad \min \\
\left.\text { sample }^{-1}\right)\end{array}$ \\
\hline regeneration & yes (at least 200 cycles) & no \\
\hline label or not & no & $\begin{array}{l}\text { yes, horseradish peroxidase } \\
\text { labeled is necessary }\end{array}$ \\
\hline
\end{tabular}


Figures<smiles>Cc1nc2ccccc2nc1C(=O)NCCO</smiles>

Olaquindox, OLA<smiles>Cc1nc2ccccc2nc1C(=O)O</smiles>

3-methyl-quinoxaline-2carboxylic acid, MQCA

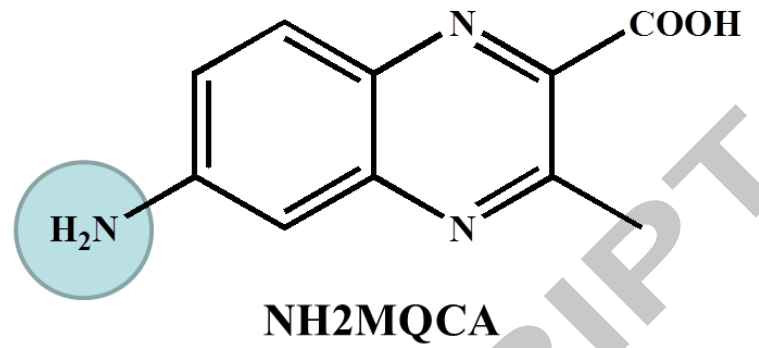

OVA<smiles>CC(=O)Nc1ccc2nc(C(=O)O)c(C)nc2c1</smiles>

NH2MQCA-OVA

Figure 1 
Format A

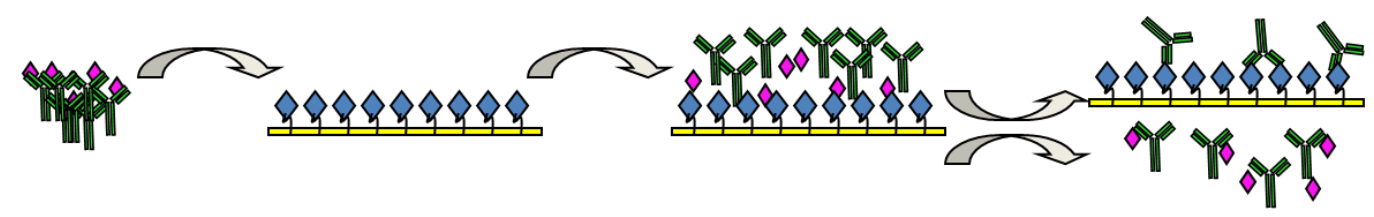

Format B

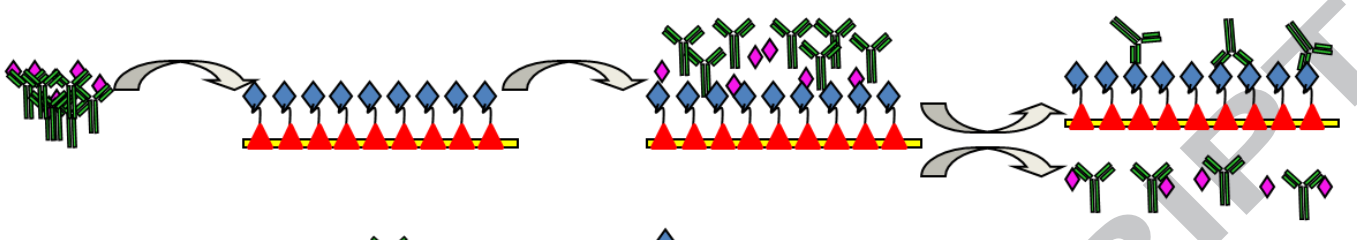




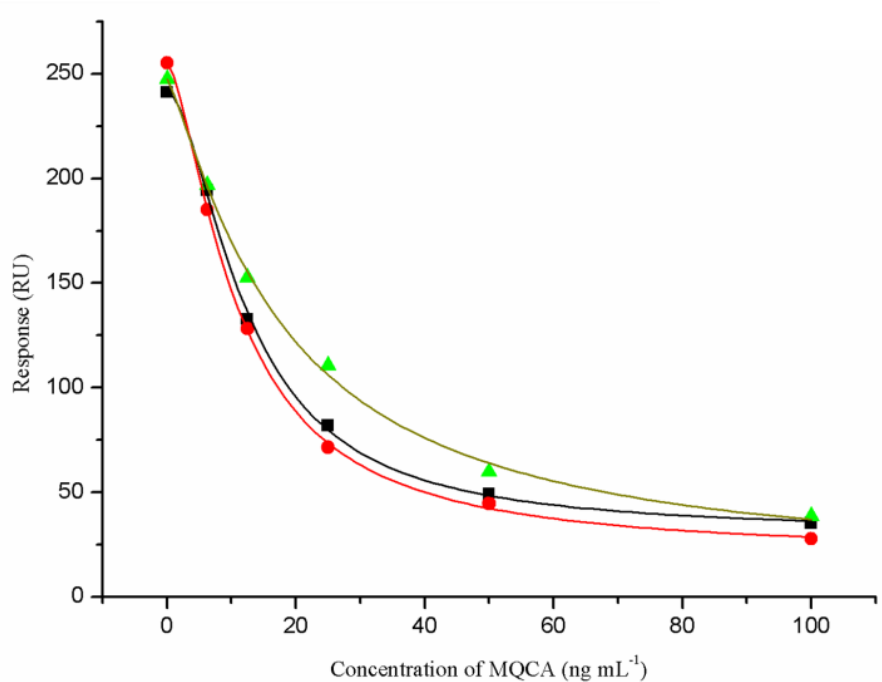

465

A.

(RU)

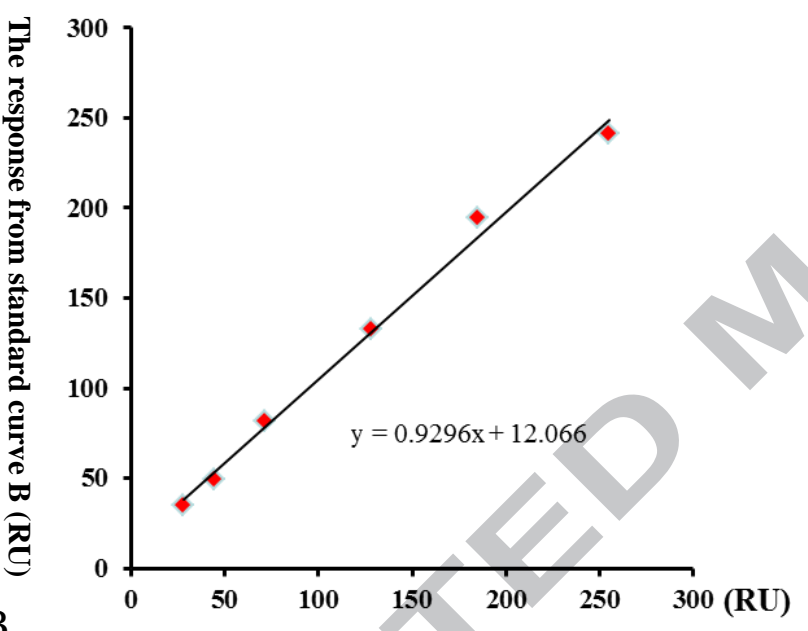

B.

The response from standard curve $A(R U)$

467

C.

(RU)

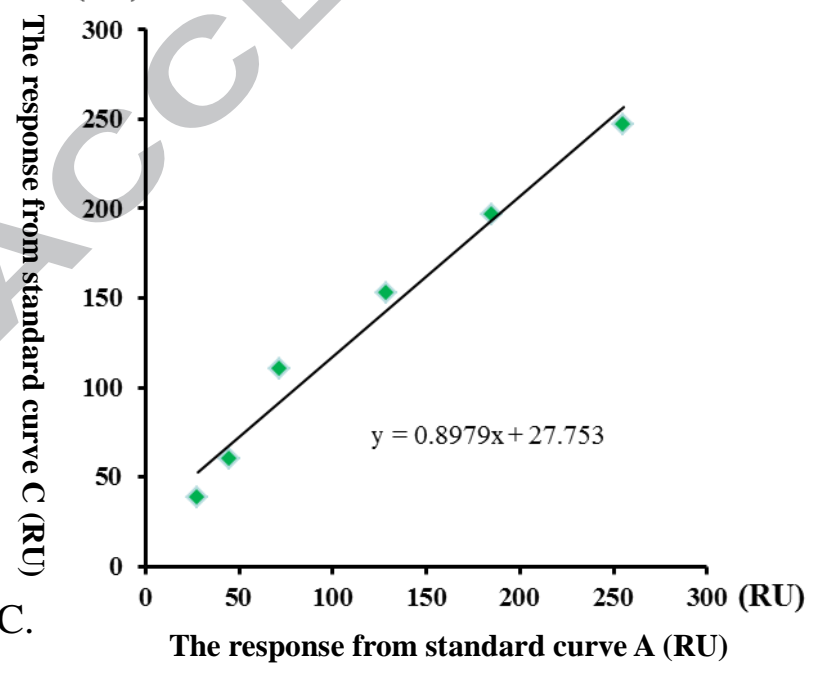

Figure 3 

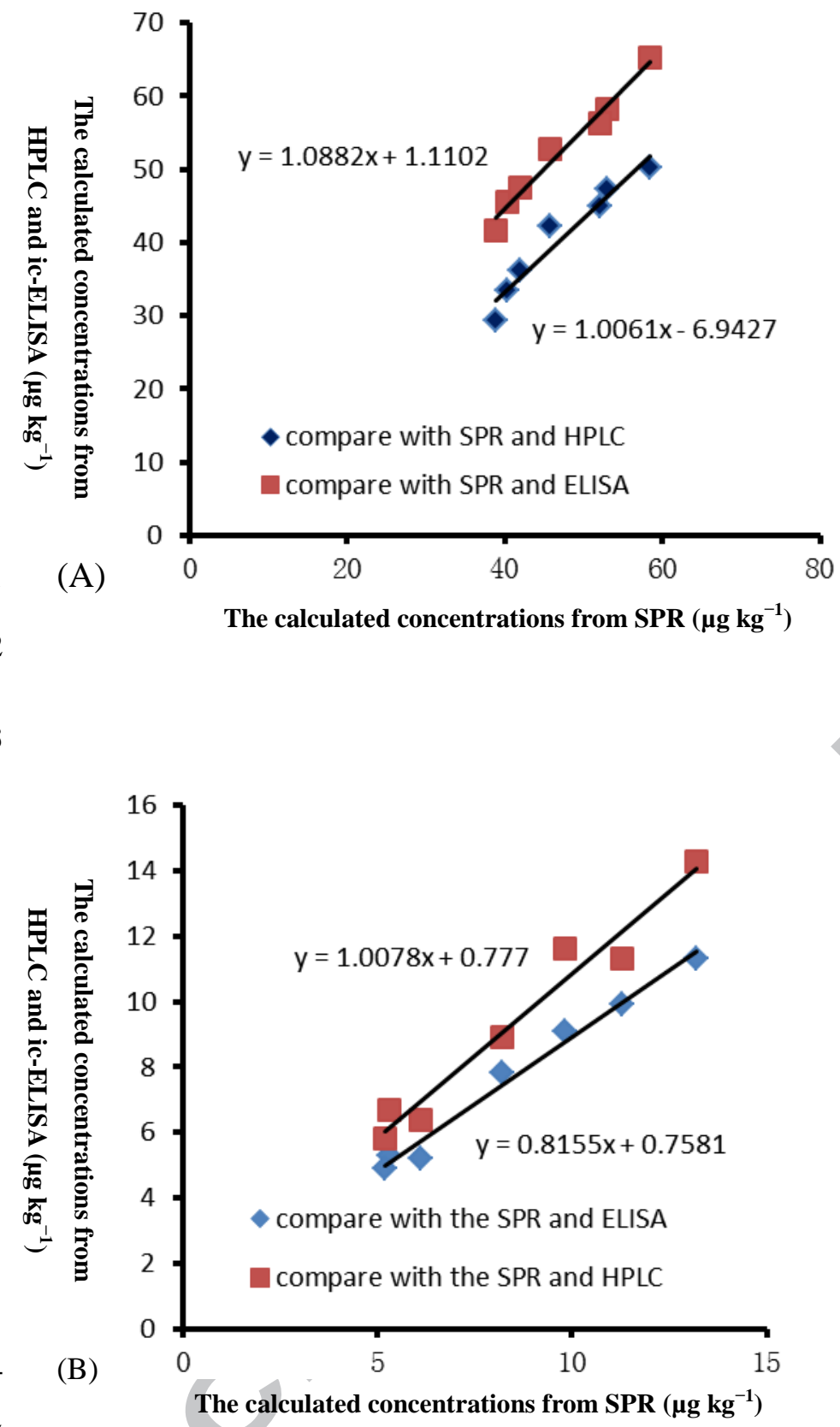


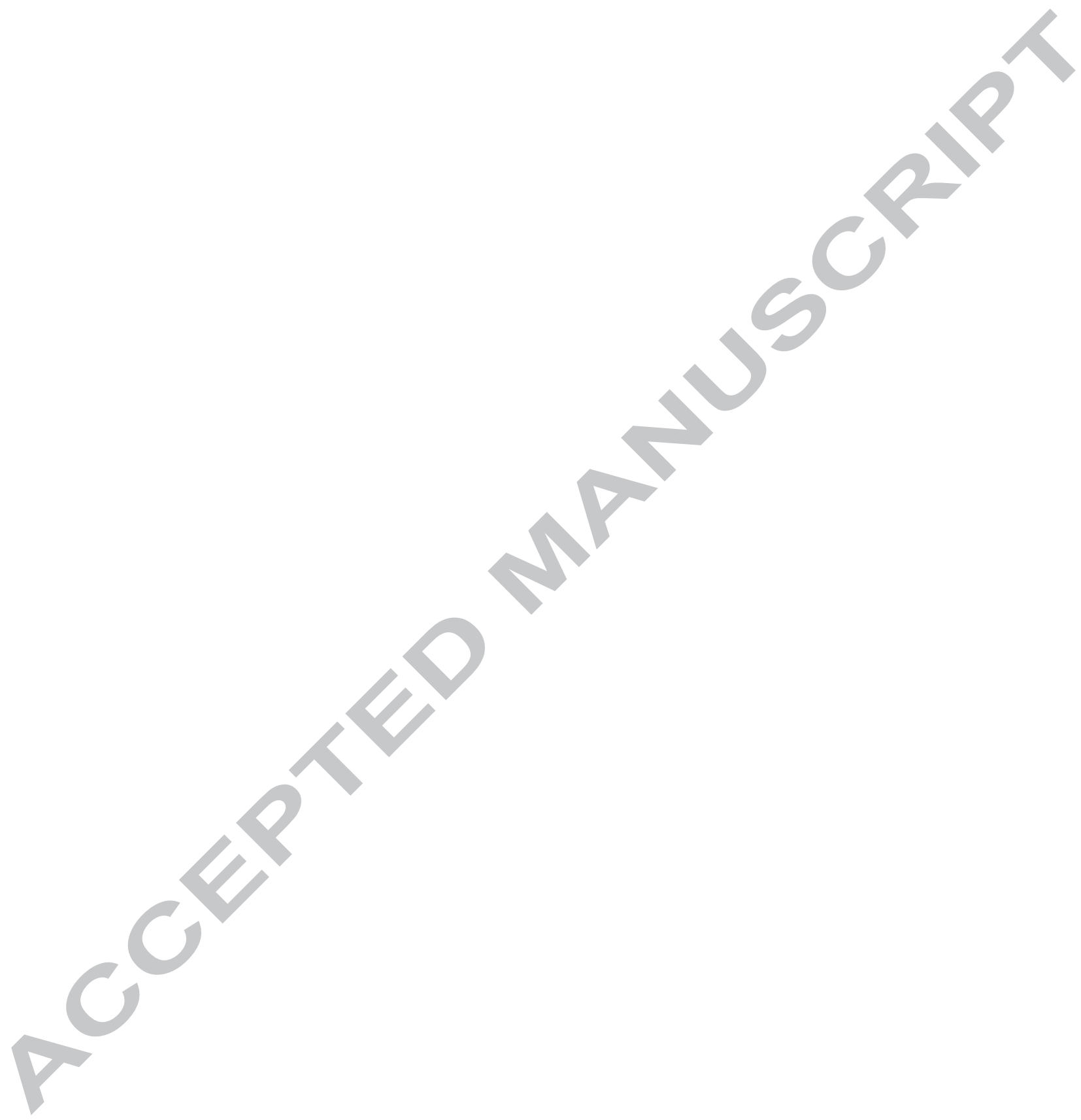




\section{Research highlights}

481

482

- A new SPR method for the determination of MQCA had been reported.

483

- The developed SPR method is the first report for MQCA in animal tissues.

484

- The SPR method can serve as an effective screening tool in any routine laboratory.

485 